\title{
Hubungan Kadar Copeptin Serum dengan Derajat Pneumonia pada anak balita
}

\author{
Rianasyah, Audrey MI Wahani, Diana Takumansang Sondakh \\ Departemen Ilmu Kesehatan Anak Fakultas Kedokteran Universitas Sam Ratulangi/RS Dr. R.D. Kandou, Manado
}

Latar belakang. Peran copeptin pada pneumonia masih merupakan kontroversi.

Tujuan. Mengetahui hubungan antara kadar copeptin serum dengan derajat pneumonia pada anak balita.

Metode. Kami melakukan penelitian secara cross sectional pada anak dengan kriteria pneumonia menurut kriteria WHO dan radiologis. Sampel diambil secara consecutive sampling dan dilakukan pemeriksaan kadar copeptin serum. Orang tua atau wali subjek penelitian diminta menandatangani inform consent. Penelitian ini dilaksanakan dibawah persetujuan Komite Etik.

Hasil. Didapatkan hasil 38 anak yang terdiri dari 25 laki-laki dan 13 perempuan dengan rerata umur 14,26 (SD 13,544) bulan. Rerata kadar copeptin serum $13.868 \mathrm{ng} / \mathrm{mL}$. Didapatkan hubungan positf antara kadar copeptin serum dengan derajat pneumonia. $(\mathrm{r}=0,781$ dan $\mathrm{p}<0,0001)$

Kesimpulan. Terdapat hubungan yang sangat bermakna dan kuat antara kadar copeptin dengan derajat pneumonia.

Sari Pediatri 2015;17(4):292-6.

Kata kunci: copeptin, anak, pneumonia

\section{Association between Serum Copeptin Level and The Severity of Pneumonia in Children under Five Years Old}

\author{
Rianasyah, Audrey MI Wahani, Diana Takumansang Sondakh
}

Background. There has been controversy in the role of serum copeptin level in pneumonia.

Objective. To assess a correlation between serum copeptin with severity of pneumonia in children under five years old.

Method. We conducted a cross-sectional study in children with pneumonia. Diagnosis was based on WHO criteria plus chest $\mathrm{x}$ ray findings. We recruited sample consecutively and examined serum copeptin level in children who met the criteria as sudy participants. Informed consents were obtained from parents or guardians. This study was approved by ethical comitte.

Results. Subjects were 38 children, consist of 25 boys and 13 girls with an average age 14.26 (SD 13.544) months. Mean serum copeptin levelwas $13,868 \mathrm{ng} / \mathrm{mL}$. We found a positive correlation between serum copeptin levelwith the severity of pneumonia. $(\mathrm{r}=0.781$ and $\mathrm{p}<0.0001)$

Conclusion. There is a significant and strong correlation between levels of serum copeptin with the degree of pneumonia. Sari Pediatri 2015;17(4):292-6.

Keywords: copeptin, children, pneumonia 
$\mathrm{P}$ neumonia merupakan masalah kesehatan utama anak di seluruh dunia dan penyebab terbanyak morbiditas dan mortalitas pada anak, terutama di bawah usia lima tahun (balita). ${ }^{1}$ Diperkirakan 2,6 juta anak balita menderita pneumonia setiap tahun dan hampir seperlimanya mengalami kematian. ${ }^{2}$ Berdasarkan Riset Kesehatan Dasar (Riskesda) kejadian pneumonia mengalami peningkatan pada tahun 2007 sebesar 2,1\% menjadi $2,7 \%$ pada tahun $2013 .^{3}$

Salah satu prediktor prognosis pneumonia adalah copeptin. ${ }^{4}$ Copeptin merupakan sebuah rantai glycopeptida 39 asam amino dengan berat molekul $5 \mathrm{kD}$, yang merupakan bagian C-terminal dari proAVP. Copeptin dilepaskan dari axis hipotalamuspituari-adrenal (axis HPA) dengan rasio yang sama dengan hormon stress vasopressin. Sekresi copeptin juga dipengaruhi oleh perubahan osmolaritas plasma, sirkulasi volume darah, faktor stres, gangguan oksigenasi, dan proses inflamasi. ${ }^{5,6}$

Penelitian tentang hubungan kadar copeptin serum dengan pneumonia pada balita sangat sedikit dan hasilnya masih kontroversi. ${ }^{7,8}$ Penilaian prognosis yang tepat mendorong klinisi untuk melakukan pemantauan yang lebih ketat, terapi yang akurat dan bisa menjadi dasar pertimbangan etik konseling untuk memberikan informasi mengenai keadaan penderita kepada orangtua. Tujuan penelitian ini untuk mengetahui hubungan antara kadar copeptin serum dengan derajat pneumonia pada anak balita.

\section{Metode}

Penelitian observasional analitik bentuk korelatif yang dilakukan dengan desain cross sectional. Penelitian dilaksanakan di RSUP Prof. Dr. R.D. Kandou, RS Pancaran Kasih, dan RS Tingkat III Teling Manado dari bulan Mei sampai dengan Agustus 2015. Subjek penelitian dikumpulkan dengan cara consecutive sampling. Kriteria inklusi adalah anak usia 2 sampai dengan 60 bulan yang memenuhi kriteria klinis pneumonia menurut WHO, gizi baik, dan mendapatkan persetujuan dari orang tua/wali dan menandatangani surat persetujuan (informed consent). Pasien dengan sepsis, sepsis berat, syok sepsis, dehidrasi berat, diabetes mellitus, penyakit jantung, TBC, defisiensi sistem imun, riwayat menderita penyakit hati dan ginjal, serta pasien yang mendapatkan pengobatan dengan kortikosteroid tidak diikutsertakan dalam penelitian.

Analisis statistik menggunakan program SPSS for windows versi 22. Uji chi-kuadrat $\left(\mathrm{x}^{2}\right)$ digunakan untuk mencari hubungan dua variabel kategorik, antara karateristik subjek dengan derajat pneumonia. Uji t tidak berpasangan digunakan untuk membandingkan rata-rata data numerik dan derajat pneumonia. Analisis regresi dan korelasi point biserial digunakan untuk melihat hubungan antar variabel. Kemaknaan hasil uji ditentukan berdasarkan nilai $\mathrm{p}<0,05$.

\section{Hasil}

Kami memperoleh 38 subjek yang memenuhi kriteria inklusi yang terdiri atas 18 anak dengan pneumonia dan 20 pneumonia berat. Tabel 1 memperlihatkan karakteristik subjek. Pada kedua jenis kelamin, kasus pneumonia berat lebih banyak dibandingkan pneumonia. Umur terendah adalah 2 bulan dan tertinggi 53 bulan, dengan rerata umur 14,26 (SD $13,544)$ bulan. Pada pneumonia, kadar copeptin

Tabel 1. Karakteristik penderita pneumonia

\begin{tabular}{lccc}
\hline & Pneumonia & $\begin{array}{c}\text { Pneumonia } \\
\text { berat }\end{array}$ & $\mathrm{p}$ \\
\hline Jenis kelamin & 12 & & \\
Laki-laki & 6 & 13 & $0,457^{*}$ \\
Perempuan & $19,06(15,37)$ & $9,95(10,2)$ & $0,025^{* *}$ \\
Umur, bulan, rerata (SB) & $9,17(1,38)$ & $18,1(4,88)$ & $0,0001^{\#}$ \\
Copeptin, ng/mL, rerata (SB) & & & \\
${ }^{*}$ Uji X & & & \\
${ }^{* *}$ Uji Mann Whitney & & & \\
${ }^{*}$ Uji t tidak berpasangan & & &
\end{tabular}


serum terendah adalah $7,0 \mathrm{ng} / \mathrm{mL}$ dan tertinggi 12,0 $\mathrm{ng} / \mathrm{mL}$, sedangkan pada pneumonia berat, kadar copeptin serum terendah $12,0 \mathrm{ng} / \mathrm{mL}$ dan tertinggi 27,0 ng/mL.

Pada Tabel 2 dan Gambar 1 terlihat hubungan positif antara kadar copeptin serum dengan derajat pneumonia dengan persamaan regresi $y=0,23+8,93 x$ dan $r_{p b}=0,781$ dan $p<0,0001$. Hasil ini menyatakan terdapat hubungan yang sangat bermakna dan bahwa insiden pneumonia per 1000 balita paling banyak dialami oleh anak berusia 12-35 bulan. ${ }^{3}$ Anak pada kelompok usia ini lebih rentan terhadap penyakit pneumonia karena imunitas yang belum sempurna, saluran pernapasan yang cukup sempit, serta tingginya prevalensi kolonisasi bakteri patogen di nasofaring. ${ }^{11}$

Kami mendapatkan hubungan positif antara kadar copeptin serum dengan derajat pneumonia pada anak

Tabel 2. Hasil analisis regresi dan korelasi

\begin{tabular}{lccc}
\hline Model & Koefisien regresi & Koefisien korelasi & Kemaknaan \\
\hline Konstanta & 0,233 & & \\
Derajat pneumonia & 8,933 & $\mathrm{rpb}=0,781$ & $\mathrm{p}<0,0001$ \\
\hline
\end{tabular}

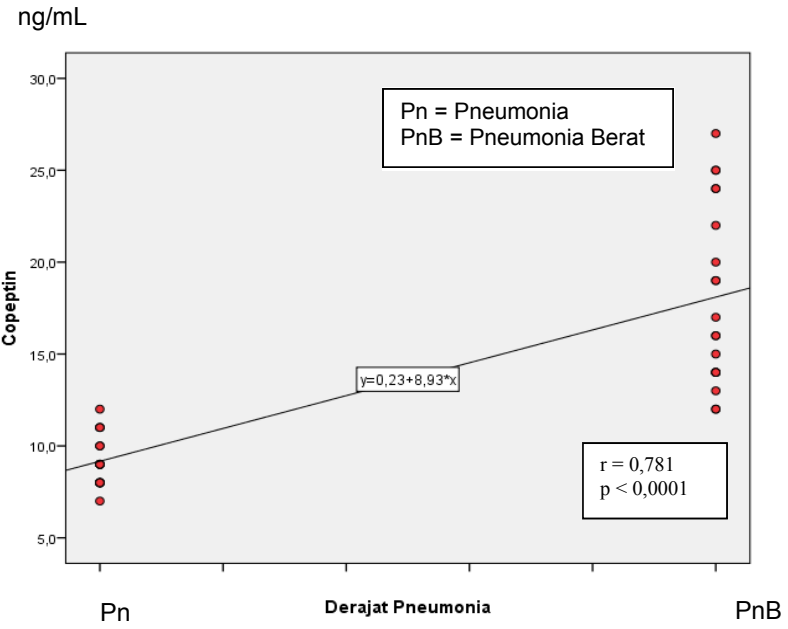

Gambar 1. Scatterplot hubungan derajat pneumonia dengan kadar copeptin

kuat antara derajat pneumonia dan kadar copeptin $(\mathrm{p}<0,0001)$.

\section{Pembahasan}

Penelitian kami memperlihatkan distribusi jenis kelamin yang sama seperti penelitian di Banda Aceh. ${ }^{9}$ Hartati $\mathrm{dkk}^{10}$ melaporkan tidak ada perbedaan yang bermakna antara jenis kelamin dengan angka kejadian pneumonia. Subjek penelitian kami berusia 2 bulan sampai 5 tahun, dengan rerata umur 14,26 bulan. Hal tersebut serupa dengan laporan Riskesdas 2013 balita. Hasil penelitian kami sesuai dengan laporan penelitian Du dkk ${ }^{7}$ yang melaporkan adanya hubungan positif antara kadar copeptin serum dengan derajat pneumonia pada anak prasekolah. Pada penelitian tersebut sampel yang dibandingkan adalah kelompok anak sehat, kelompok anak community acquired pneumonia (CAP) tanpa komplikasi, dan kelompok anak CAP dengan komplikasi. Kadar copeptin serum meningkat pada kelompok CAP dengan komplikasi dibandingkan dengan kelompok CAP tanpa komplikasi dan kelompok anak sehat. Komplikasi yang terjadi pada CAP (efusi pleura, pneumotorak, pneumotokel, abses paru) ini menentukan derajat keparahan pneumonia dan meningkatkan risiko kematian pada anak di bawah 5 tahun. ${ }^{12}$

Penelitian lain pada anak usia 8 hari sampai dengan 18 tahun dengan pneumonia mendapatkan hasil yang berbeda. Hasil penelitian tersebut melaporkan tidak ada hubungan yang bermakna antara derajat pneumonia dengan kadar copeptin. Derajat pneumonia pada penelitian ini ditentukan berdasarkan gejala klinis (suhu, pernafasan, nadi) dan laboratorium (leukosit, neutrofil, CRP, dan procalcitonin). Namun, subjek dengan peningkatan kadar copeptin di atas rerata $(0,33 \mathrm{ng} / \mathrm{mL})$ cenderung mengalami peningkatan suhu tubuh. Di samping itu, mereka memperlihatkan adanya perbedaan yang bermakna antara kadar copeptin pada subjek kelompok CAP dengan kelompok sehat. ${ }^{8}$

Peningkatan kadar copeptin pada pneumonia diduga disebabkan oleh gangguan oksigenasi jaringan, 
pelepasan sitokin interleukin (IL)-1 $\beta$, IL-6, tumor nekrosis faktor (TNF)- $\alpha$. Faktor-faktor tersebut akan meningkatkan respon stres, selanjutnya mengaktivasi sistem saraf otonom, yaitu HPA axis. Copeptin bersama dengan neurophysin II dan AVP akan disekresi dari neuron magnoselular di nukleus supraoptik dan paraventrikular hipotalamus sebagai prohormon dalam bentuk granul. ${ }^{13,14}$

Beberapa penelitian pada pasien pneumonia dewasa menunjukkan hasil yang sesuai dengan penelitian kami. Muller $\mathrm{dkk}^{15}$ dan Kolditz $\mathrm{dkk}^{16}$ melaporkan kadar copeptin meningkat secara signifikan pada pasien pneumonia dibandingkan dengan kelompok yang sehat. Derajat keparahan pneumonia pada kedua penelitian tersebut diukur dengan pneumonia severity index (PSI), skor CRB-65, dan mortalitas. Dilaporkan pula kadar copeptin meningkat secara bermakna sesuai dengan derajat keparahan pneumonia. Kedua penelitian tersebut menyimpulkan copeptin merupakan marker prognostik yang lebih baik dibandingkan parameter lain, seperti CRP dan leukosit. Oleh karena itu, kadar copeptin bisa dijadikan marker dalam memprediksi prognostik pasien dengan CAP. ${ }^{15}$

Keterbatasan penelitian ini adalah jumlah subjek yang minimal dan tidak mengontrol faktor berapa lama pemakaian antibiotik sebelum masuk rumah sakit yang dapat berpengaruh terhadap kadar copeptin serum.

\section{Kesimpulan}

Terdapat hubungan positif antara kadar copeptin serum dengan derajat pneumonia. Diperlukan penelitian lanjutan dengan desain kohort prospektif untuk melihat dinamika kadar copeptin serum dalam perjalanan penyakit (keberhasilan terapi, kegagalan organ, maupun mortalitas).

\section{Daftar pustaka}

1. Rudan I, Pinto CB, Biloglav Z, Mulholland K, Campbell H. Epidemiology and etiology of childhood pneumonia. Bull World Heath Organ 2008;86:408-16.

2. Madhi SA, De WP, Grijava CG, Grimwood K, Grossman $\mathrm{R}$, Ishiwada N, dkk. The burden of childhood pneumonia in the develop world: a review of the literature. Pediatr Infect Dis J 2013;32:119-27.
3. Kementerian Kesehatan Republik Indonesia. Riset kesehatan dasar. Jakarta: Badan Penelitian dan Pengembangan Kesehatan. Kementerian Kesehatan RI;2013.

4. Seligman R, Papassotiriou J, Morgenthaler NG, Meisner M, Teixeira PJ. Copeptin, a novel prognostic biomarker in ventilator associated pneumonia. Crit Care 2008;12:1-9.

5. Jochberger S, Morgenthaler NG, Mayr VD, Luckner G, Wenzel V, Ulmer H, dkk. Copeptin and arginine vasopressin concentrations in critically ill patients. J Clin Endocrinol Metab 2006;91:4381-6.

6. Dobsa L, Edozien KC. Copeptin and its potentioal role in diagnosis and prognosis of various diseases. Biochem Medica 2013;23:172-90.

7. Du JM, Sang G, Jiang CM, He XJ, Han Y. Relationship between plasma copeptin levels and complications of community acquired pneumonia in preschool children. Peptides 2013:45.61-5.

8. Wrotek A, Jackowska T, Pawlik K. Sodium and copeptin levels in children with community acquired pneumonia. Advs Exp Med Biol 2015;4:1-6.

9. Mauli S. Karakteristik balita yang menderita pneumonia di wilayah kerja Puskesmas Kota Sigli Kabupaten Pidie tahun 2013, [Karya Tulis Ilmiah]. Banda Aceh: STIKes Ubudiyah, 2013.

10. Hartati S. Analisis faktor risiko yang berhubungan dengan kejadian pneumonia pada anak balita di RSUD Pasar Kebo Jakarta, [Karya Tulis Ilmiah].Jakarta: Program Magister Ilmu Keperawatan Universitas Indonesia; 2011.

11. Said M. Pneumonia. Dalam: Rahajoe NN, Supriyatno $\mathrm{B}$, Setyanto DB, penyunting. Buku ajar respirologi anak. Edisi ke-1. Jakarta: Badan Penerbit IDAI;2008.h.35065.

12. Pinto KD, Maggi RR, Alves JG. Analysis of social and environmental risk for pleural involvement in severe pneumonia in children younger than 5 years of age. Rev Panam Salud Publica 2004;15:104-9.

13. Boeck L, Eggimann P, Smyrnios N, Pargger H, Thakkar $N$, Siegemund M, dkk. The sequential organ failure assessment score and copeptin for predicting survival in ventilator associated pneumonia. J Crit Care 2012;27:521-9.

14. Katan M, Christ CM. The stress hormone copeptin: a new prognostic biomarker in acute illness. Swiss Med Wkly 2010;140:1-6.

15. Muller B, Morgenthaler N, Stolz D, Schuetz P, Muller C, Bingisser R, dkk. Circulating levels of copeptin, a 
Rianasyah dkk: Hubungan kadar copeptin serum dengan derajat pneumonia

novel biomarker, in lower respiratory tract infections. Eur J Clin Invest 2007;37:145-52.

16. Kolditz M, Halank M, Schulte-Hubbert B, Bergmann
S, Albrecht S, Hoffken G. Copeptin predicts clinical deterioration and persistent instability in communityacquired pneumonia. Respir Med 2012;106:1320-8. 